\title{
Enabling External Factors for Inflation Rate Forecasting using Fuzzy Neural System
}

\author{
Nadia Roosmalita Sari ${ }^{1}$, Wayan Firdaus Mahmudy ${ }^{2}$, Aji Prasetya Wibawa ${ }^{3}$, Elta Sonalitha ${ }^{4}$ \\ ${ }^{1,2}$ Faculty of Computer Science, Universitas Brawijaya \\ ${ }^{4}$ Faculty of Information Technology, University of Merdeka Malang \\ ${ }^{3}$ Faculty of Engineering, Universitas Negeri Malang
}

\section{Article Info}

Article history:

Received Dec 10, 2016

Revised Jun 7, 2017

Accepted Aug 11, 2017

\section{Keywords:}

Forecasting

Fuzzy neural system (FNS)

Inflation

Root mean square error

(RMSE)

\begin{abstract}
Inflation is the tendency of increasing prices of goods in general and happens continuously. Indonesia's economy will decline if inflation is not controlled properly. To control the inflation rate required an inflation rate forecasting in Indonesia. The forecasting result will be used as information to the government in order to keep the inflation rate stable. This study proposes Fuzzy Neural System (FNS) to forecast the inflation rate. This study uses historical data and external factors as the parameters. The external factor using in this study is very important, which inflation rate is not only affected by the historical data. External factor used are four external factors which each factor has two fuzzy set. While historical data is divided into three input variables with three fuzzy sets. The combination of three input variables and four external factors will generate too many rules. Generate of rules with too many amounts will less effective and have lower accuracy. The novelty is needed to minimalize the amount of rules by using two steps fuzzy. To evaluate the forecasting results, Root Means Square Error (RMSE) technique is used. Fuzzy Inference System Sugeno used as the comparison method. The study results show that FNS has a better performance than the comparison method with RMSE that is 1.81 .
\end{abstract}

Copyright $@ 2017$ Institute of Advanced Engineering and Science. All rights reserved.

\section{Corresponding Author:}

Nadia Roosmalita Sari,

Faculty of Computer Science, Universitas Brawijaya, Jalan Veteran, Malang, Indonesia,

Faculty of Information Technology, University of Merdeka Malang, Jalan Dieng Raya, Malang, Indonesia,

Email: nadiaroosmalitasari@gmail.com

\section{INTRODUCTION}

Economic growth can be used to assess the development of a country. Economic growth means the physical development of goods and services production existing in a country [1]. On the other hand, inflation is the tendency of increasing prices of goods in general and happens constantly [2]. Therefore, it may influence the national economic growth. In other words, inflation could be used as a tool to measure the economic development of a country.

Inflation can occur due to the high consumptive patterns of society. For example, the high employment opportunities creates a high level of income and further raises expenditures that exceed the economic ability of exceeding goods and services. So that the consumptive patterns of society will increase. Moreover, inflation can also occur due to increased prices of imports from their regions. The lower the degree of imported goods competition to domestic products, the greater the impact happens to the changes in the price of imported goods to the inflation. Inflation is often encountered by developing countries, such as Indonesia. Indonesia's economy will decline if inflation is not controlled properly. One of the problems caused by inflation is continuous currency debasement. Indirectly, the debasement may affect to the global trading activities. As a result, it may increase the cost of daily necessities and raise the spread of unemployment quantity. 
Forecasting system is required to control the inflation rate required. It aims to provide information to the government for anticipating the future inflation. On the other hand, the forecasting results can be utilized by the community at large. For investors, the forecasting results can be used as investment information. The high inflation rate means that the investor could increase the investments on property is possibly more profitable. Forecasting is made based on historical data with time-series analysis technique, of the previous months the inflation occurs. This study will also use some external factors to determine the level of inflation. Historical data and external factors are used as an input variable, while the output data is the forecasting results. External factors used in this study include the Consumer Price Index (CPI), the BI Rate, Money supply, and Exchange rate. The external factors have been used in several studies [3-8].

Inflation rate forecasting has been done by Moser, et al [9] and [10]. Moser, et al used Auto Regression Integrated Moving Average (ARIMA) to forecast the inflation rate. Then Baciu used stochastic model to forecast the inflation rate [10].

Recent study has used Backpropagation Neural Network (NN) as a method to forecast the inflation rate. Sari, et al used historical data and CPI as input variables. Accuracy obtained using method Backpropagation NN method is 0.204 [2]. The accuracy technique used is the Root Mean Square Error (RMSE). Neural Network has the advantage that is more flexible in terms of adapting and has a good ability to learn. Neural Network is able to detect patterns and trends in various data sets [12], but Neural Network is weak in explaining something. Therefore, it needs to be combined with fuzzy logic that has a good ability in explaining. This study is an advanced study from the previous study [2]. This study proposes Fuzzy Neural System (FNS) as a method that is capable to produce a better accuracy as compared to the previous study [2].

\section{CURRENT STUDY}

Zhang and Li [13] used the SVR model to forecast inflation rate in China. SVR is a method used in making decisions. This method can be considered as the improvement of Linear Regression, where this method is able to generate a function with wavy results follow the data path formed. Therefore, the forecasting result becomes more accurate as compared to linear regression. The accuracy of the system using the RMSE is 0.1 .

In the previous study, Sari [2] used Backpropagation Neural Network to forecast the inflation rate. The study used historical data and CPI as input variable. The RMSE of the system obtained by using Backpropagation Neural Network is 0.204. In addition to forecast inflation rate, Neural Network is also used for forecasting the rising demand for electric vehicles applicable to Indian Road Conditions [14]. Based on their study, Poorani and Murugan [15] said that Neural Network is particularly effective in handling outliers. Neural Network has a good ability to learn, but this model has a weakness in explaining things. Therefore a Fuzzy Neural System (FNS) as the inflation rate forecasting method to improve the forecasting accuracy.

In terms of a forecasting, fuzzy logic has been successfully implemented in the forecasting problems using time-series data [16]. Fuzzy Neural System (FNS) has been used by [17] for modeling the nonlinear system. While Wibawa et al [12] used a combination of fuzzy logic and neural network to forecast the foreign exchange. This level of accuracy generated by using Mean Square Error (MSE) technique is 0.201.

\section{THE DATA SET}

This study uses the dataset in the form of historical data from Bank Indonesia [18] and the Badan Pusat Statistik [19]. The data record that used is 99 data ranging from October 2005 - Desember 2013.

Parameters used in this study are historical data with time-series analysis (b-1, b-2, b-3). b-1 parameter represents a month before, $b-2$ represents two months before, and b-3 represents three months before. This study also use several external factors which affect to the inflation rate, like CPI, BI rate, Money Supply, and Exchange Rate. Those parameters used as input variable in inflation rate forecasting. Whereas output variable is in the form of the inflation rate forecasting result in Indonesia. Table 1 and Table 2 are showing the data record to each variable. 
Table 1. Internal Variable Based on Time Series Analysis

\begin{tabular}{ccccc}
\hline Date & Actual data & b-1 & b-2 & b-3 \\
\hline Dec-13 & 8.38 & 8.37 & 8.32 & 8.40 \\
Nov-13 & 8.37 & 8.32 & 8.40 & 8.79 \\
Oct-13 & 8.32 & 8.40 & 8.79 & 8.61 \\
Sep-13 & 8.40 & 8.79 & 8.61 & 5.90 \\
Aug-13 & 8.79 & 8.61 & 5.90 & 5.47 \\
Jul-13 & 8.61 & 5.90 & 5.47 & 5.57 \\
Jun-13 & 5.90 & 5.47 & 5.57 & 5.90 \\
May-13 & 5.47 & 5.57 & 5.90 & 5.31 \\
Apr-13 & 5.57 & 5.90 & 5.31 & 4.57 \\
Mar-13 & 5.90 & 5.31 & 4.57 & 4.30 \\
Feb-13 & 5.31 & 4.57 & 4.30 & 4.32 \\
Jan-13 & 4.57 & 4.30 & 4.32 & 4.61 \\
$\ldots$ & $\ldots$ & $\ldots$ & $\ldots$ & $\ldots$ \\
Oct-05 & 17.89 & 9.06 & 8.33 & 7.84 \\
\hline
\end{tabular}

Table 2. External Variabes

\begin{tabular}{cccccc}
\hline Date & Actual data & CPI & Money supply & BI Rate & Exchange rate \\
\hline Dec-13 & 8.38 & 146.84 & 870455.00 & 7.50 & 11977.00 \\
Nov-13 & 8.37 & 146.04 & 856146.00 & 7.25 & 11234.00 \\
Oct-13 & 8.32 & 145.87 & 867721.00 & 7.25 & 11613.00 \\
Sep-13 & 8.40 & 145.74 & 855783.00 & 7.00 & 10924.00 \\
Aug-13 & 8.79 & 146.25 & 879986.00 & 6.50 & 10278.00 \\
Jul-13 & 8.61 & 144.63 & 858557.00 & 6.50 & 9929.00 \\
Jun-13 & 5.90 & 140.03 & 822930.00 & 6.00 & 9802.00 \\
May-13 & 5.47 & 138.60 & 832273.00 & 5.75 & 9722.00 \\
Apr-13 & 5.57 & 138.64 & 810112.00 & 5.75 & 9719.00 \\
Mar-13 & 5.90 & 138.78 & 786606.00 & 5.75 & 9667.00 \\
Feb-13 & 5.31 & 137.91 & 787916.00 & 5.75 & 9698.00 \\
Jan-13 & 4.57 & 136.88 & 841722.00 & 5.75 & 9651.50 \\
$\ldots$ & $\ldots$ & $\ldots$ & $\ldots$ & $\ldots$ & $\ldots$ \\
Oct-05 & 17.89 & 135.15 & 273954.00 & 11.00 & 10310.00 \\
\hline
\end{tabular}

\section{TWO STAGES FUZZY LOGIC FOR INFLATION RATE FORECASTING}

Fuzzy logic used as comparison method as well as part of Fuzzy Neural System (FNS) method. The output generated by fuzzy logic will be used as input to the Neural Network. Fuzzy Inference System (FIS) Sugeno is a model from fuzzy logic used to forecast the inflation rate in Indonesia. FIS Sugeno developed by Takaghi, Sugeno, and Kang (TSK) [20]. This Fuzzy Inference System chosen because this model is suitable for time-series data such as in the study [16]. FIS Sugeno consists of three processes, including the fuzzification process, fuzzy inference engine, and defuzzification.

\subsection{Fuzzification}

Input variables in this study will be divided into two or more fuzzy sets. Fuzzy set is a union representing certain circumstances in a fuzzy variable [21]. Linguistic variables are united with fuzzy set, each of which has a membership function that has been defined [22]. Membership function is a curve showing the representation of the input point data into membership values that has interval between 0-1. Function to determine the membership value is described by Triangular fuzzy number [23]. Figure 1 shows an example of a Triangular fuzzy number representing input variables $b-1, b-2$ and $b-3$ [24]. Figure 2 represents the external variables.

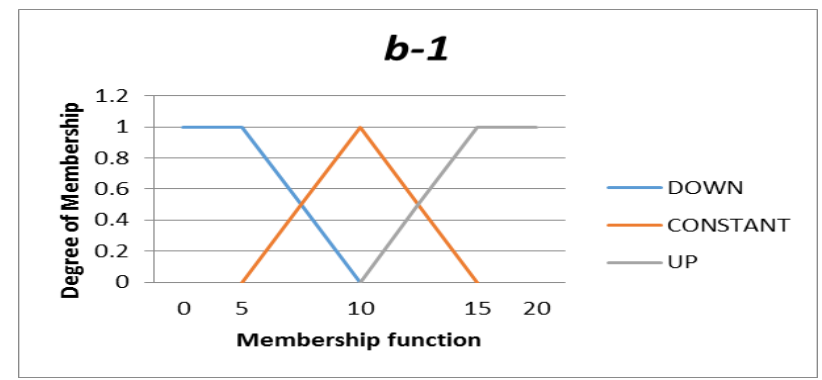

Figure 1. An example of variable input time-series 


$$
\begin{gathered}
\mu \text { DOWN }(x)=\left\{\begin{array}{cc}
1 & x \leq 5 \\
\frac{10-x}{5} & 5<x<10 \\
0 & x \geq 10
\end{array}\right. \\
\mu U P(x)=\left\{\begin{array}{cc}
\frac{0-10}{5} & x \leq 10 \\
1 & x \geq 15
\end{array}\right. \\
\mu \operatorname{ConstanT}(x)=\left\{\begin{array}{cc}
\frac{x-(-5)}{5} & 5<\text { and }(x \geq 15) \\
\frac{15-x}{5} & 10<x<10 \\
1 &
\end{array}\right.
\end{gathered}
$$

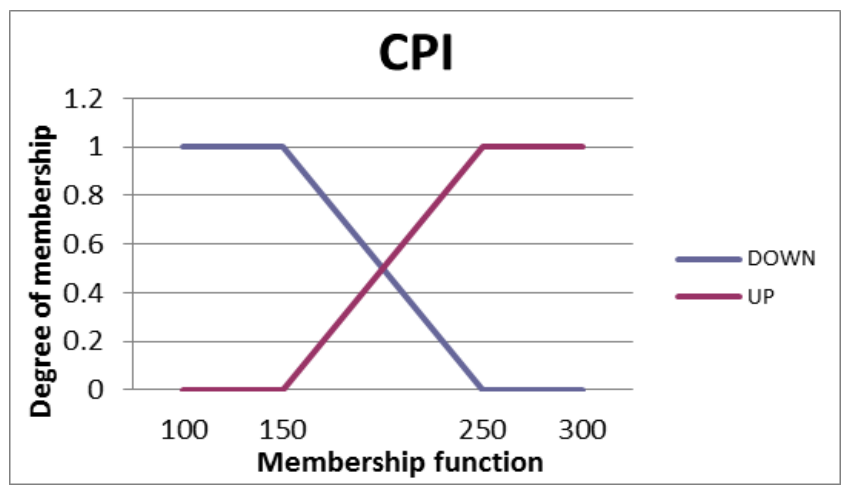

Figure 2. An example of variable input external factors

$$
\begin{array}{r}
\mu \text { DOWN }(x)=\left\{\begin{array}{c}
1 \\
\frac{250-x}{100} \\
0
\end{array}\right. \\
\mu U P(x)=\left\{\begin{array}{c}
0 \\
\frac{x-150}{100} \\
1
\end{array}\right.
\end{array}
$$

$$
\begin{gathered}
x \leq 150 \\
150<x<250 \\
x \geq 250 \\
x \leq 150 \\
150<x<250 \\
x \geq 250
\end{gathered}
$$

\subsection{Fuzzy Inference Engine}

The results of the calculation process of fuzzy membership valued then inferenced to the fuzzy rules. At the FIS Sugeno method, implication function used is Min. Table 3 is an example of fuzzy rules used in this study. The number of fuzzy rules obtained from the number of fuzzy set and then it power the number of input variables. For the example, there are three input variables and two fuzzy sets. So that the number of fuzzy rules obtained is eight fuzzy rules. In this study, each of fuzzy logic has a number of different rules. The first fuzzy logic (positive parameters) has 5 input variables with 2 fuzzy set and 3 fuzzy set. Therefore, the number fuzzy rules are 36. While, the second fuzzy logic (negative parameters) has 2 input variables with 2 fuzzy set. Then, there are 4 rules in negative parameters. The positive and negative parameters describe in Figure 3 and Figure 4 below. This classification of parameters aims to minimize fuzzy rules. If not classified, there are 144 rules. Generating too many rules not effective and need more time. 
Table 3. An Example of Fuzzy Rules

\begin{tabular}{ll}
\hline No & Fuzzy Rules \\
\hline $\mathrm{R} 1$ & $\mathrm{IF}(b-1)$ is UP AND $(b-2)$ is UP AND $(b-3)$ is UP... THEN z $=\mathrm{a}+\mathrm{b} 1 *(b-1)+\mathrm{b} 2 *(b-2)+\ldots$ \\
$\mathrm{R} 2$ & $\mathrm{IF}(b-1)$ is DOWN AND $(b-2)$ is UP AND $(b-3)$ is DOWN $\ldots$ THEN z $=\mathrm{a}+\mathrm{b} 1 *(b-1)+\mathrm{b} 2 *(b-2)+\ldots$ \\
$\mathrm{R} 3$ & $\mathrm{IF}(b-1)$ is UP AND $(b-2)$ is DOWN AND $(b-3)$ is UP $\ldots$ THEN z $=\mathrm{a}+\mathrm{b} 1 *(b-1)+\mathrm{b} 2 *(b-2)+\ldots$ \\
$\mathrm{R} 4$ & $\mathrm{IF}(b-1)$ is UP AND $(b-2)$ is UP AND $(b-3)$ is DOWN $\ldots$ THEN z $=\mathrm{a}+\mathrm{b} 1 *(b-1)+\mathrm{b} 2 *(b-2)+\ldots$ \\
$\mathrm{R} 5$ & $\mathrm{IF}(b-1)$ is CONSTANT AND $(b-2)$ is DOWN AND $(b-3)$ is UP $\ldots$ THEN z $=\mathrm{a}+\mathrm{b} 1 *(b-1)+\mathrm{b} 2 *(b-2)+\ldots$ \\
\hline
\end{tabular}

\subsection{Defuzzification}

The output value (crisp) obtained by changing the input into a number in the fuzzy set or that referred to defuzzification. Defuzzification method in the Sugeno method is Center Average Defuzzyfier.

To decrease the amount of fuzzy rules that are so many, this study uses two stages fuzzy technique, that is grouped the parameters which have the positive and negative influence to the inflation rate. It is said positive parameter if the parameter can control the price level [24]. Money Supply and CPI are often used by Indonesian government to control the price level. They are can be categorized as positive parameters. Besides that, historical data also can be categorized into the positive parameter. The rest can be categorized into the negative parameter showed in Table 4 . Figure 3 and Figure 4 describe the two stages of fuzzy structure.

Table 4. An Positive and Negative Parameters as Input Variables

\begin{tabular}{cc}
\hline \multicolumn{2}{c}{ Parameters } \\
\hline Positive & Negative \\
\hline$b-1$ & Exchange rate \\
$b-2$ & BI rate \\
$b-3$ & \\
CPI & \\
Money Supply & \\
\hline
\end{tabular}

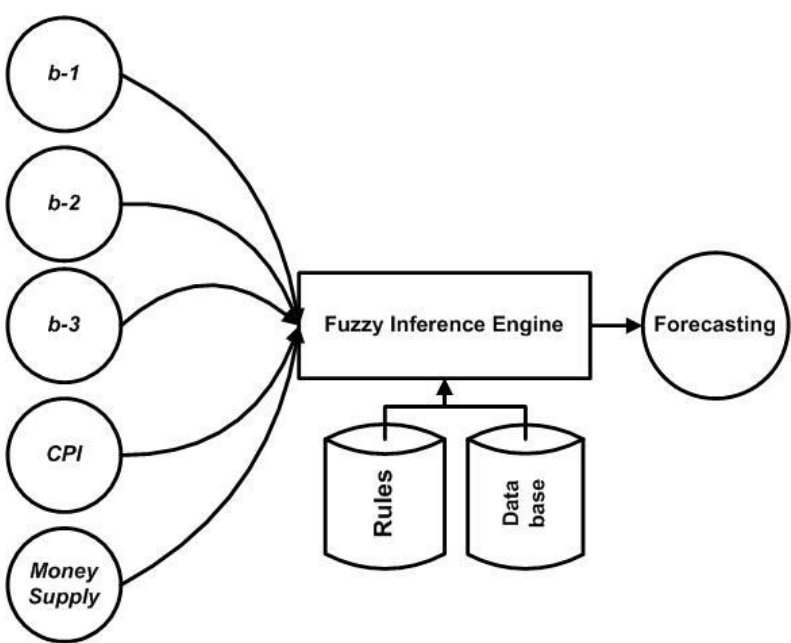

Figure 3. Fuzzy structure with positive parameter

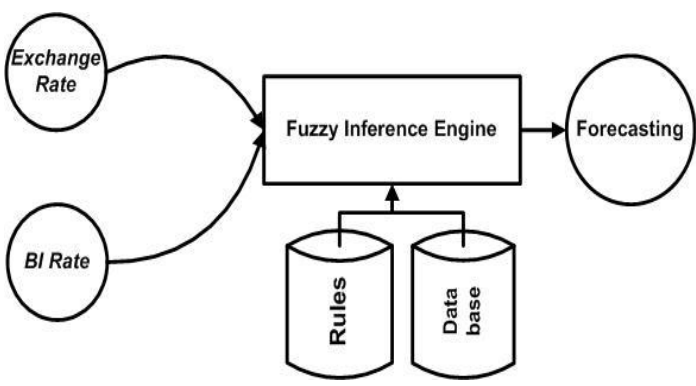

Figure 4. Fuzzy structure with negative parameter

Based on the two stages fuzzy test results, each of these processes produce output that is in the form of inflation forecasting. The forecasting results are shown in Table 5. Data processing result using two stages fuzzy, it used as an input variables to be processed using Neural Network. 
Table 5. The Inflation Rate Forecasting in Indonesia on Each Parameter

\begin{tabular}{cccc}
\hline Date & Actual data & \multicolumn{2}{c}{ Forecasting result } \\
& & FIS Sugeno I & $\begin{array}{c}\text { FIS Sugeno II } \\
\text { Parameter }+\end{array}$ \\
\hline 13-Dec & 8.38 & 8.85048 & 12.4735 \\
13-Nov & 8.37 & 8.773 & 11.31075 \\
13-Oct & 8.32 & 8.75544 & 11.68975 \\
13-Sep & 8.4 & 9.18091 & 10.581 \\
13-Aug & 8.79 & 9.68373 & 9.0955 \\
13-Jul & 8.61 & 6.692 & 8.7465 \\
13-Jun & 5.9 & 6.13282 & 7.78 \\
13-May & 5.47 & 6.13014 & 7.28025 \\
13-Apr & 5.57 & 6.64419 & 7.27725 \\
13-Mar & 5.9 & 6.16127 & 7.22525 \\
13-Feb & 5.31 & 5.37959 & 7.25625 \\
13-Jan & 4.57 & 5.06216 & 7.20975 \\
\% & $\ldots$ & $\ldots$ & $\ldots$ \\
5-Oct & 17.89 & 17.13 & 18.56175 \\
\hline
\end{tabular}

\section{THE PROPOSED METHOD}

In Section 5, the study proposes Fuzzy Neural System (FNS) as inflation forecasting method. FNS is a hybrid method between FIS Sugeno and Backpropagation Neural Network. Figure 5 illustrates the structure of Backpropagation Neural Network [26].

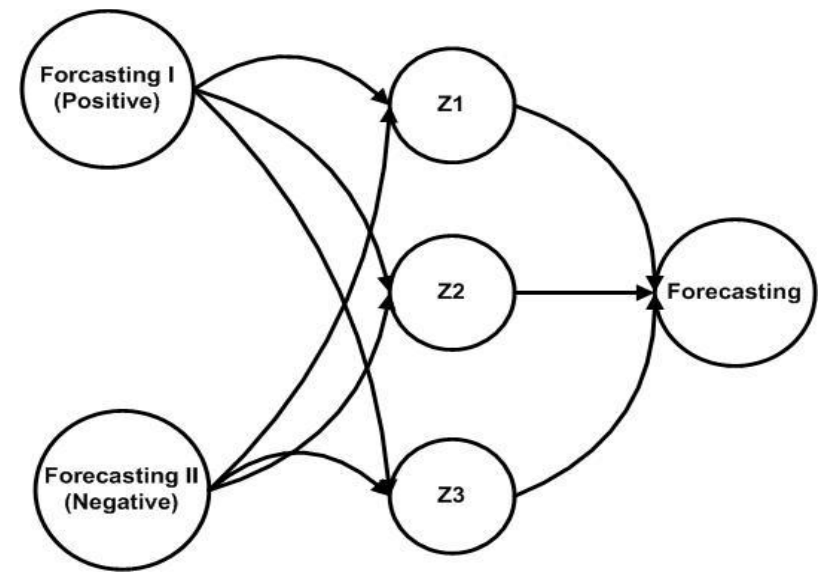

Figure 5. The Backpropagation Neural Network's structure.

(Adapted by Saif et al, 2013)

Having obtained the fuzzy output in Section 4, the next stage is the training data process. The training data process in Neural Network is a learning data process. The data that will be used in the training data process data are 70 data records (April 2008 - December 2013) taken from each input variable. Input variable in this stage is in the form of output predictions generated by the FIS Sugeno process in Section 4. In the proposed method used 3 neuron hidden layers, namely $Z 1, Z 2$, and $Z 3$. The number of hidden layer is determined to minimize the computational process. However, use some of hidden layer will minimize error value.

\section{NUMERICAL EXAMPLE}

Backpropagation Neural Network has two stages working mechanism, namely feedforward and backpropagation. In the feedforward stage, it is conducted the training data process that is the learning data process. The training data process also involves the learning rate testing process. Learning rate testing is carried out together with training data process. The test results can be used for testing the data at the further stage that is testing the number of epoch. In this stage it is used 69 data records (April 2008 - December 2013) to training data process. The results of learning rate testing shown in Table 6. 
Table 6. The Learning Rate Testing Result on Each Experiment

\begin{tabular}{cccccccc}
\hline \multirow{2}{*}{$\begin{array}{c}\text { Learning } \\
\text { rate }\end{array}$} & Epoch & \multicolumn{5}{c}{ Experiment } \\
\cline { 3 - 7 } & & 1 & 2 & 3 & $\ldots$ & 10 & $\begin{array}{c}\text { Error } \\
\text { average }\end{array}$ \\
\cline { 3 - 7 } & 2000 & 0.002758 & 0.002756 & 0.002754 & $\ldots$ & 0.002743 & 0.001101 \\
0.1 & 2000 & 0.002644 & 0.002666 & 0.002667 & $\ldots$ & 0.002669 & 0.001065 \\
0.2 & 2000 & 0.002628 & 0.002652 & 0.002618 & $\ldots$ & 0.002639 & 0.001054 \\
0.3 & 2000 & 0.002626 & 0.00261 & 0.002619 & $\ldots$ & 0.002619 & 0.001047 \\
0.4 & 2000 & 0.00263 & 0.002625 & 0.002635 & $\ldots$ & 0.002678 & 0.001057 \\
0.5 & 2000 & 0.002675 & 0.002617 & 0.002653 & $\ldots$ & 0.002642 & 0.001059 \\
0.6 & 2000 & 0.00263 & 0.00265 & 0.002597 & $\ldots$ & 0.002654 & 0.001053 \\
0.7 & 2000 & 0.002642 & 0.002668 & 0.002653 & $\ldots$ & 0.002669 & 0.001063 \\
0.8 & 2000 & 0.002676 & 0.002681 & 0.002682 & $\ldots$ & 0.002673 & 0.001071 \\
0.9 & 2000 & 0.002646 & 0.002687 & 0.002695 & $\ldots$ & 0.002687 & 0.001071 \\
1 & & & & & & & \\
\hline
\end{tabular}

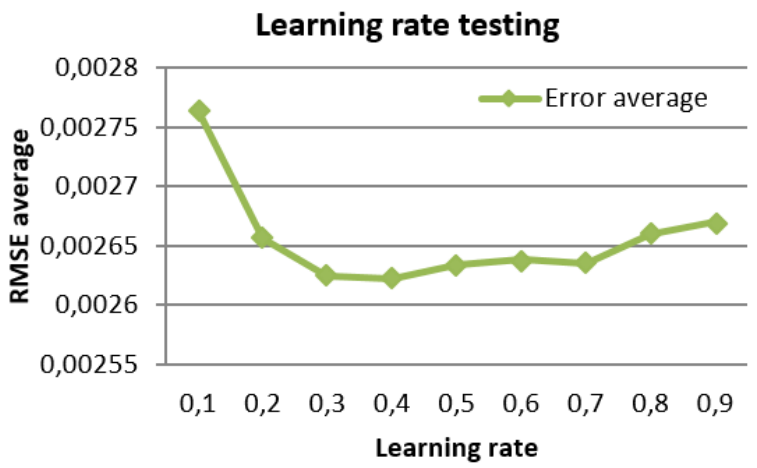

Figure 6. Learning rate testing graph

In Figure 6 known that the learning rate movement chart look down and suddenly up. Basically, the smaller the value of learning rate then the learning process will be longer to reach the target. In addition, the target may not be achieved due to the condition of the epoch stopped before reaching the target so that the error generated is still high. However, the large value of learning rate will make the learning process faster. The faster of the learning process will allow the target to be exceeded. Therefore, the resulting error tends in this analysis tends to be high. It can be concluded that the value of learning rate which is has small and large rates are difficult to achieve the target. It also influenced by the different data. In this test the best value for learning rate is 0.4 . The values are selected based on the smallest error average is 0.001047 that shown in Table 6.

After obtained the best learning rate value, that value is used to test the amount of epoch. Testing is performed 10 times. This test aims to get the best epoch that use to find the number of neurons in further testing. The test result is shown in Table 7.

Table 7. The Number of Epoch Testing Result on Each Experiment

\begin{tabular}{|c|c|c|c|c|c|c|c|}
\hline \multirow{3}{*}{$\begin{array}{c}\text { Learning } \\
\text { rate }\end{array}$} & \multirow{3}{*}{ Epoch } & \multicolumn{5}{|c|}{ Experiments } & \multirow{3}{*}{$\begin{array}{c}\text { Error } \\
\text { average }\end{array}$} \\
\hline & & 1 & 2 & 3 & $\ldots$ & 10 & \\
\hline & & \multicolumn{5}{|c|}{ RMSE } & \\
\hline 0.4 & 5000 & 0.002596 & 0.00254 & 0.002579 & $\ldots$ & 0.002577 & 0.002563 \\
\hline 0.4 & 10000 & 0.002444 & 0.002468 & 0.002448 & $\ldots$ & 0.002449 & 0.002488 \\
\hline 0.4 & 30000 & 0.002359 & 0.002364 & 0.002388 & $\ldots$ & 0.002395 & 0.002399 \\
\hline 0.4 & 50000 & 0.002315 & 0.002333 & 0.002348 & $\ldots$ & 0.002332 & 0.002338 \\
\hline 0.4 & 100000 & 0.00225 & 0.002224 & 0.002389 & $\ldots$ & 0.002228 & 0.002287 \\
\hline 0.4 & 150000 & 0.002182 & 0.002208 & 0.002193 & $\ldots$ & 0.00218 & 0.002189 \\
\hline 0.4 & 200000 & 0.002169 & 0.00249 & 0.00249 & $\ldots$ & 0.002164 & 0.002264 \\
\hline 0.4 & 250000 & 0.002153 & 0.002153 & 0.002154 & $\ldots$ & 0.002155 & 0.002153 \\
\hline 0.4 & 300000 & 0.002147 & 0.002149 & 0.002147 & $\ldots$ & 0.002149 & 0.002206 \\
\hline 0.4 & 320000 & 0.002145 & 0.002389 & 0.002147 & $\ldots$ & 0.002148 & 0.002193 \\
\hline
\end{tabular}




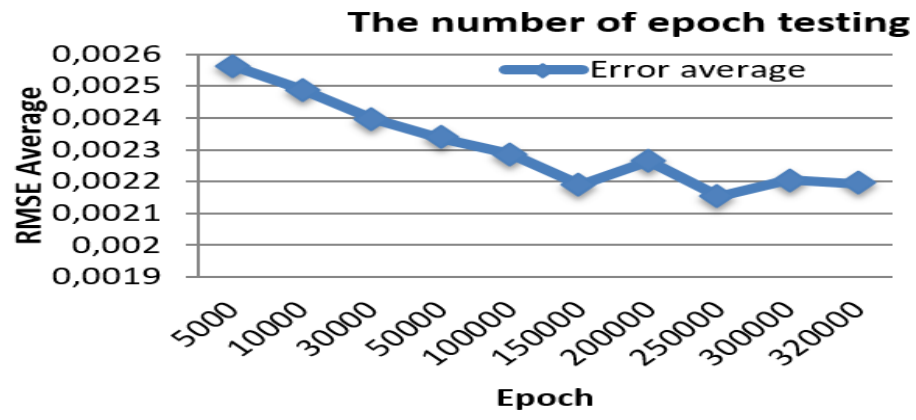

Figure 7. The number of epoch testing

Figure 7 shows the movement of the epoch seemed to decline. This is because the more epoch that used, then learning process will reaching the target fastly, so the resulting error is smaller. However, to get that result, it can take a lot of time in computing process. In this testing the best of epoch is 250000 . The value are selected based on the the smallest of error average is 0.002153 as shown in Table 7 .

Having obtained the best of learning value and the number of epoch, then further testing has done the testing of neuron. Some neural network structures are tested for evaluating the optimal network considering the number of neuron in the hidden layer [27]. The result of these tests are used in the next stages is data processing using Neural Network. The testing neuron performed 10 times. The result of neuron testing is shown in Table 8.

Table 8. The Number of Neuron Testing Result on Each Experiment

\begin{tabular}{|c|c|c|c|c|c|c|c|c|}
\hline \multirow{3}{*}{ Neuron } & \multirow{3}{*}{$\begin{array}{c}\text { Learning } \\
\text { Rate }\end{array}$} & \multirow{3}{*}{ Epoch } & \multicolumn{5}{|c|}{ Experiments } & \multirow{3}{*}{$\begin{array}{c}\text { Error } \\
\text { average }\end{array}$} \\
\hline & & & 1 & 2 & 3 & $\ldots$ & 10 & \\
\hline & & & \multicolumn{5}{|c|}{ RMSE } & \\
\hline 3 & 0.4 & 250000 & 0.002142 & 0.002153 & 0.002152 & $\ldots$ & 0.002389 & 0.002177 \\
\hline 4 & 0.4 & 250000 & 0.002113 & 0.002149 & 0.002119 & $\ldots$ & 0.002161 & 0.00213 \\
\hline 5 & 0.4 & 250000 & 0.002109 & 0.00212 & 0.002109 & $\ldots$ & 0.00212 & 0.002169 \\
\hline 6 & 0.4 & 250000 & 0.002097 & 0.002115 & 0.00211 & $\ldots$ & 0.002111 & 0.002112 \\
\hline 7 & 0.4 & 250000 & 0.002093 & 0.00211 & 0.002103 & $\ldots$ & 0.002109 & 0.00211 \\
\hline 8 & 0.4 & 250000 & 0.002099 & 0.002103 & 0.002137 & $\ldots$ & 0.002096 & 0.002125 \\
\hline 9 & 0.4 & 250000 & 0.002122 & 0.002111 & 0.002112 & $\ldots$ & 0.002094 & 0.002112 \\
\hline 10 & 0.4 & 250000 & 0.002103 & 0.002117 & 0.002114 & $\ldots$ & 0.002111 & 0.002114 \\
\hline
\end{tabular}

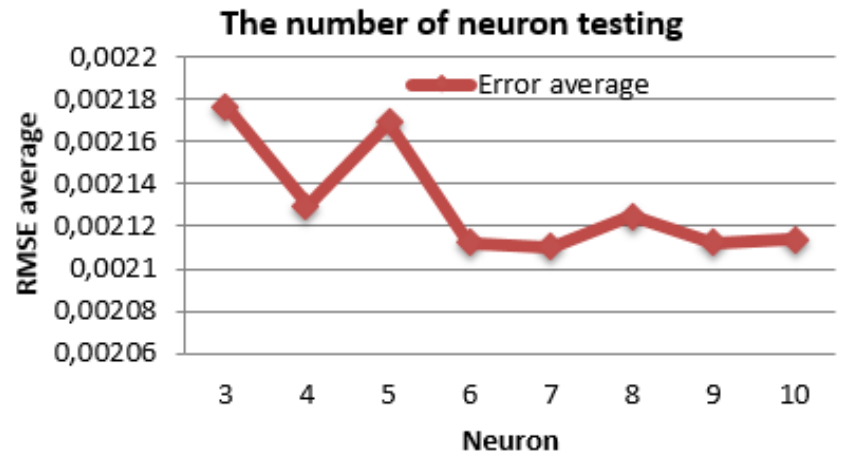

Figure 8. The number of neuron testing

Figure 8 shows the movementof error average decreases as the number of neurons. This is because more and more neurons are used, the result of error is getting smaller. However, it can take a lot of time in the computing process. In this test the best neuron is 7 . The value are selected based on the smallest of error average is 0.00211 as shown in Table 8 .

Based on the test result, the number of neurons obtained the best weights to be used for testing data. The weights are summarized in Table 9. Vij is weight from neuron input to neuron hidden. Then, Wjk is weight from neuron hidden to neuron output. 
Table 9. The Weights Obtained During the Training Process

\begin{tabular}{cccccccc}
\hline Vij & 1 & 2 & 3 & 4 & 5 & 6 & 7 \\
\hline 1 & -0.801 & 1.11978 & -1.7285 & -1.0278 & -15.993 & -1.5049 & -4.5577 \\
2 & -0.1697 & -0.2628 & 0.89545 & 0.091 & 19.6983 & 0.63894 & 6.66133 \\
\hline
\end{tabular}

\begin{tabular}{cc}
\hline $\mathrm{Wjk}$ & 1 \\
\hline 1 & -2.9618 \\
2 & 5.24921 \\
3 & -3.3891 \\
4 & -3.037 \\
5 & -1.649 \\
6 & -3.1919 \\
7 & 3.98781 \\
\hline
\end{tabular}

\section{RESULT AND DISCUSSION}

In this stage, it is conducted the data testing to get the results of inflation forecasting in Indonesia. The data testing is done after obtaining the value of learning rate and the best weight on the training data process. The best value of learning rate in the training data process is 0.4 with computation time is 1 second.

The next process is data testing. Data used in the testing stage are 30 data (October 2005 - March 2008). This stage is Backpropagation mechanism to produce an inflation rate forecasting in Indonesia. To test the accuracy of the system, this study uses Root Mean Square Error (RMSE) technique. This technique is easy to implement and has been frequently used in variety of studies related to the forecasting, as in the study by Stock and Watson [28] and Sari, et al [29]. Table 10 shows the forecasting results using FNS.

Table 10. The Forecasting Result betwen FNS and FIS Sugeno Method

\begin{tabular}{|c|c|c|c|}
\hline Bulan & Actual data & FIS Sugeno & FNS \\
\hline Mar-08 & 8.17 & 4.74536 & 5.629177 \\
\hline Feb-08 & 7.4 & 4.93495 & 5.688712 \\
\hline Jan-08 & 7.36 & 4.20774 & 5.579564 \\
\hline Dec-07 & 6.59 & 4.27898 & 5.566819 \\
\hline Nov-07 & 6.71 & 4.71617 & 5.672624 \\
\hline Oct-07 & 6.88 & 4.94409 & 5.724522 \\
\hline Sep-07 & 6.95 & 4.71438 & 5.840431 \\
\hline Aug-07 & 6.51 & 4.38733 & 5.644035 \\
\hline Jul-07 & 6.06 & 4.04482 & 5.534054 \\
\hline Jun-07 & 5.77 & 4.426 & 5.687975 \\
\hline Мay-07 & 6.01 & 4.88781 & 6.077364 \\
\hline Apr-07 & 6.29 & 5.42047 & 7.004558 \\
\hline Mar-07 & 6.52 & 5.20755 & 7.180982 \\
\hline Feb-07 & 6.3 & 5.43999 & 7.973428 \\
\hline Jan-07 & 6.26 & 6.31525 & 8.345952 \\
\hline$\ldots$ & $\ldots$ & $\ldots$ & $\ldots$ \\
\hline 5-Oct & 17.89 & 18.03852 & 15.50373 \\
\hline \multicolumn{2}{|c|}{ RMSE } & 3.54 & 1.81 \\
\hline
\end{tabular}

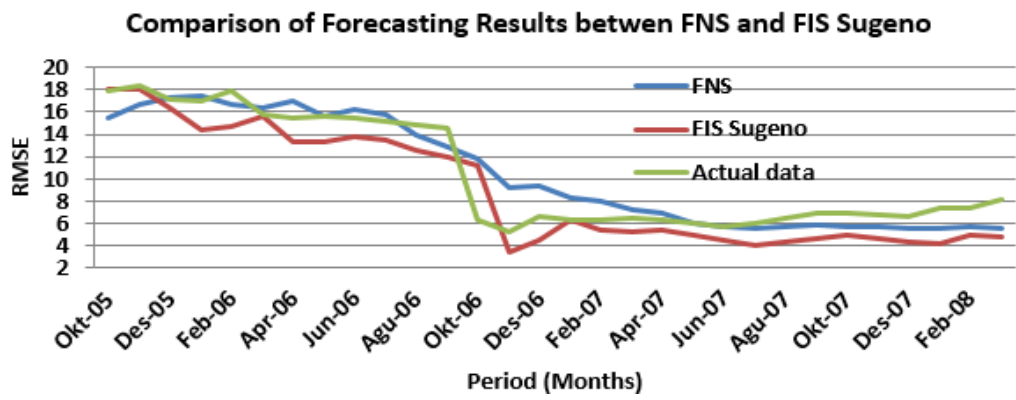

Figure 9. The results of the comparison method between FNS and FIS Sugeno for inflation rate forecasting

This study is advanced study from previous study [30]. In the previous study used Fuzzy Inference System (FIS) Sugeno approach for inflation rate forecasting. Time series and external factors used in that 
study [30]. Accuracy of forecasting result by using FIS Sugeno is 3.54. Previous study [30] used as a comparison method. Table 10 shows a comparison between the proposed method and the comparison method. In Figure 9 it is known that the FNS shows the movement that closer to the actual data. By using RMSE technique, the accuracy of the system generated by FNS is 1.81 . While the accuracy generated by the comparison method is 3.54. Based on Table 10 FNS method has a better performance and makes a better prediction than the comparison method. This result can occur because FNS model there is a process of training data neural network so that this method is more flexible in terms of adapting to the environment and have good learning ability.

\section{CONCLUSION}

Fuzzy Neural System (FNS) method that is proposed in this study can be implemented for the inflation rate forecasting in Indonesia. The result of RMSE calculation shows that FNS has a better performance than the comparison method FIS Sugeno (previous study)[30]. With the addition of some external parameters (external factor), the forecasting result using FNS method is also better than using Backpropagation Neural Network in previous study[11]. The accuracy of the system produced by FNS using RMSE analysis technique is 1.81 .

The accuracy of the system resulted in this study can still be improved. One of the things that affect the accuracy of the system is the formation of fuzzy rules and determining the initial weights in the Neural Network training process. In this study, the determination of fuzzy rules determined manually. While the initial weights in training process are still determined randomly. It might be that such a determination is less fit. Therefore, genetic algorithm implementation in the next study is needed to optimize the fuzzy rules and the initial weights in training data process. Optimization aims to improve the accuracy of the system that is better. Genetic Algorithm has been used to resolve issues related to the optimization like a study conducted by [31].

Provide a statement that what is expected, as stated in the "Introduction" chapter can ultimately result in "Results and Discussion" chapter, so there is compatibility. Moreover, it can also be added the prospect of the development of research results and application prospects of further studies into the next (based on result and discussion).

\section{REFERENCES}

[1] S. Sukirno, "Pengantar Teori Makro Ekonomi (Introduction to the Theory of Macro Economy)". Jakarta: PT Raja Grafindo Persada, 2008.

[2] N. R. Sari, W. F. Mahmudy, and A. P. Wibawa, "Backpropagation on Neural Network Method for Inflation Rate Forecasting in Indonesia," Int J Soft Comput Its Appl, 2016.

[3] E. R. Wulan and S. Nurfaiza, "Analysis of Factors Affecting Inflation in Indonesia: an Islamic Perspective," Int. J. Nusant. Islam, vol. 2, no. 2, pp. 67-80, 2015.

[4] S. Kooths, T. Mitze, and E. Ringhut, "Inflation Forecasting-a Comparison between Econometric Methods and a Computational Approach Based on genetic-neural fuzzy rule-bases," in Computational Intelligence for Financial Engineering, 2003. Proceedings. 2003 IEEE International Conference on, 2003, pp. 183-190.

[5] G. P. Zhang, "Time Series Forecasting Using A Hybrid ARIMA and Neural Network Model," Elsevier, vol. 50, pp. $159-175,2003$.

[6] J. Arlt and M. Arltova, "Forecasting of the Annual Inflation Rate in the Unstable Economic Conditions," 2015, pp. 231-234.

[7] Y. Tang and J. Zhou, "The Performance of PSO-SVM in Inflation Forecasting," in Service Systems and Service Management (ICSSSM), 2015 12th International Conference on, 2015, pp. 1-4.

[8] DM Atia, "Modeling and control PV-wind hybrid system based on fuzzy logic control technique," TELKOMNIKA Telecommunication, Computing, Electronics and Control., vol. 10, no. 3, pp. 431-441, 2012.

[9] G. Moser, F. Rumler, and J. Scharler, "Forecasting Austrian inflation," Elsevier, vol. 24, no. 3, pp. 470-480, 2007.

[10] I.-C. Baciu, "Stochastic Models for Forecasting Inflation Rate. Empirical Evidence from Romania," Procedia Econ. Finance, vol. 20, pp. 44-52, 2015.

[11] N. R. Sari, W. F. Mahmudy, and A. P. Wibawa, "Backpropagation on Neural Network Method for Inflation Rate Forecasting in Indonesia," Int. J. Soft Comput. Its Appl., 2016.

[12] A. P. Wibawa and R. Soelaiman, "Effectiveness Analysis Method of Hybrid Neural Networks and Fuzzy Logic for Forecasting Foreign Exchange," 2007.

[13] L. Zhang and J. Li, “Inflation Forecasting Using Support Vector Regression,” 2012, pp. 136-140.

[14] S. Poorani and R. Murugan, "A Non-Linear Controller for Forecasting the Rising Demand for Electric Vehicles applicable to Indian Road Conditions," International Journal of Electrical and Computer Engineering (IJECE), vol. 6, no. 5, pp. 2274-2281, 2016.

[15] H.K. Palo and Mihir Narayan Mohanty, "Classification of Emotional Speech of Children Using Probabilistic Neural Network," International Journal of Electrical and Computer Engineering (IJECE), vol. 5, no. 2, p. 311 317, 2015. 
[16] X. Xie, L. Lin, and S. Zhong, "Process Takagi-Sugeno model: A novel approach for handling continuous input and output functions and its application to time series prediction," Knowl.-Based Syst., vol. 63, pp. 46-58, Jun. 2014.

[17] H.-G. Han, Lu-MingGe, and Jun-FeiQiao, "An adaptive second order fuzzy neural network for non linear system modeling," Elsevier, 2016.

[18] "Data - Bank Indonesia (The Data - Bank Indonesia)." [Online]. Available: http://www.bi.go.id/en/moneter/inflasi/data/Default.aspx. [Accessed: 22-Oct-2015].

[19] "Uang Beredar - Portal Data Indonesia - data.go.id.” [Online]. Available: http://data.go.id/dataset/uang-beredar. [Accessed: 11-Sep-2016].

[20] C. Abdelmoula, H. Rouabeh, and M. Masmoudi, "Behavior Control of a New Designed Mobile Robot Based on Fuzzy Logic and Neuro Fuzzy Approaches for Monitoring Wall," Int. J. Intell. Eng. Syst., vol. 6, no. 3, pp. 17-26, 2013.

[21] N. R. Sari and W. F. Mahmudy, "Tsukamoto Fuzzy Inference System to Determine The Feasibility of Prospective Employees," SESINDO 2015, 2015.

[22] G. Balaji, R. Balamurugan, and L. Lakshminarasimman, "Fuzzy Clustered Multi Objective Differential Evolution for Thermal Generator Maintenance Scheduling,” Int. J. Intell. Eng. Syst., vol. 9, no. 1, pp. 1-13, Mar. 2016.

[23] M. Rezaei and M. Rezaei, "A Fuzzy Expert System for Facial Expression Recognition," J. Telecommun. Electron. Comput. Eng. JTEC, vol. 7, no. 1, pp. 37-41, 2015.

[24] R. A. Shaikh, "Fuzzy Risk-based Decision Method for Vehicular Ad Hoc Networks," IJACSA Int. J. Adv. Comput. Sci. Appl., vol. 7, no. 9, pp. 54-62, 2016.

[25] "Pengaruh Tingkat Suku Bunga, Jumlah Uang Yang Beredar Dan Inflasi Terhadap Pertumbuhan Ekonomi | bantai tugas." [Online]. Available: https://bantaitugas.wordpress.com/2013/03/31/pengaruh-tingkat-suku-bunga-jumlahuang-yang-beredar-dan-inflasi-terhadap-pertumbuhan-ekonomi/. [Accessed: 11-Sep-2016].

[26] S. M. Saif, M. Sarikhani, and F. Ebrahimi, "An Expert System with Neural Network and Decision Tree for Predicting Audit Opinions," IAES Int. J. Artif. Intell., vol. 2, no. 4, p. 151, 2013.

[27] U. R. Saxena and S. P. Singh, "Multi-Party Security System using Artificial Neural Networks," IAES Int. J. Artif. Intell., vol. 1, no. 3, p. 121, 2012.

[28] J. H. Stock and M. W. Watson, "Forecasting Infation," Elsevier, vol. 44, pp. 293-335.

[29] N. R. Sari, W. F. Mahmudy, and A. P. Wibawa, "Inflation Rate Forecasting through Adaptive Neuro Fuzzy Inference System," AICIT, vol. 8, no. 1, pp. 11-19, Mar. 2017.

[30] N. R. Sari, W. F. Mahmudy, and A. P. Wibawa, "Mengukur Performa Model TSK Fuzzy Logic Menggunakan Faktor Eksternal untuk Peramalan Laju Inflasi (Measuring the Performance of Fuzzy Logic TSK Model Using External Factors for Inflation Rate Forecasting)," MATICS, vol. 9, no. 1, p. 27, Mar. 2017.

[31] W. F. Mahmudy, "Optimization of Part Type Selection and Machine Loading Problems in Flexible Manufacturing System Using Variable Neighborhood Search,” IAENG Int. J. Comput. Sci., vol. 42, no. 3, 2015. 